\title{
Kajian Brand Equity dan City Branding terhadap Keputusan Mengunjungi Objek Wisata
}

\author{
Oleh: \\ Terra Saptina Maulani ${ }^{1}$, Mohamad Hadi Prasetyo ${ }^{2}$ \\ ${ }^{1-2}$ Program Studi S1 Manajemen, Sekolah Tinggi Ilmu Ekonomi (STIE) Ekuitas, Bandung \\ E-mail: ${ }^{1}$ terra.saptina@ekuitas.ac.id. ${ }^{2}$ hadi.p@ekuitas.ac.id
}

\begin{abstract}
ABSTRAK
Sektor pariwisata dapat menggerakkan perekonomian daerah di samping sektor industri. Potensi pariwisata di Indonesia memiliki banyak keanekaragaman di setiap wilayah karena faktor geografis dan demografi. Kebijakan pemerintah sangat mendukung pengembangan pariwisata di berbagai daerah untuk mendorong pertumbuhan ekonomi dan kesejahteraan masyarakat. Salah satu daerah di provinsi Jawa Barat yang memiliki potensi wisata alam dan budaya adalah Karawang. Dalam upaya meningkatkan jumlah kunjungan, diperlukan strategi untuk membangun objek wisata dan merek kota. Objek penelitian ini adalah destinasi wisata alam dan budaya di Karawang. Metode penelitian dalam penelitian ini adalah verifikasi deskriptif, dengan alat pengumpulan data berupa kuesioner. Sampel dalam penelitian ini adalah 400 responden yang merupakan wisatawan nasional dan internasional. City Branding secara bersamaan mempengaruhi tentang keputusan untuk mengunjungi objek wisata alam dan budaya di Karawang sebesar 53,1\%.
\end{abstract}

Kata Kunci: Brand Equity, City Branding, Keputusan, Karawang.

\begin{abstract}
The tourism sector can drive the region's economy in addition to the industrial sector. Tourism potential in Indonesia has a lot of diversity in each region due to geographical and demographic factors. Government policy strongly supports the development of tourism in different regions to encourage economic growth and welfare of the people. One area in West Java province which has the potential of natural and cultural attractions are Karawang. In an effort to increase the number of visits, it requires a strategy to build a tourism object and city brand. The object of this research is natural and cultural tourism destinations in Kawarang. The research method in this study is descriptive verification, with data collection tools in the form of questionnaires. The sample in this study were 400 respondents which national and international tourist. City Branding simultaneously on the decision to visit natural and cultural tourism objects in Karawang by $53.1 \%$
\end{abstract}

Keywords: Brand Equity, City Branding, decision, Karawang

\section{I.PENDAHULUAN}

Perkembangan perekonomian saat ini sangat pesat tidak hanya di sektor industri manufaktur, juga industri jasa. Salah satu sektor yang dapat mendorong perekonomian di daerah adalah sektor pariwisata, seperti halnya yang tercantum dalam Undang Uandang No. 10 Tahun 2009 bahwa kepariwisataan bertujuan untuk meningkatkan pertumbuhan ekonomi, meningkatkan kesejahteraan rakyat, menghapus kemiskinan, mengatasi pengangguran, melestarikan alam, lingkungan dan sumber daya, memajukan kebudayaan, mengangkat citra bangsa, memupuk rasa cinta tanah air, memperkukuh jati diri dari kesatuan bangsa dan mempererat persahabatan antar bangsa. Provinsi Jawa Barat merupakan salah satu provinsi dengan tingkat kunjungan yang tinggi di setiap tahunnya (data Gambar 1.1). 
Semakin meningkatnya kunjungan wisatawan berdampak juga pada Pendapatan Asli Daerah Provinsi Jawa Barat dari sektor pariwisata sebesar Rp. 683.743.391.66. Dalam upaya mengembangkan kepariwisataan Jawa Barat dituangkan dalam Rencana Induk Pembangunan Kepariwisataan Jawa Barat tahun 2015-2025 dengan salah satu kebijakan yang dikembangkan dalam destinasi pariwisata adalah dengan pembangunan 8 (delapan) KPPP (Kawasan Pengembangan Pariwisata Provinsi), salah satunya adalah Kawasan Pariwisata Heritage Karawang- Bekasi dan sekitarnya.

Kabupaten Karawang memiliki daya tarik wisata warisan budaya dan wisata alam yaitu Pantai Tanjung Pakis, Pantai Tanjung Baru, Pantai Pisangan, Makam Syakh Kuro, Situs Candijiwa, dan Monumen Rengasdengklok (Disparbud Jabar, 2017), dengan adanya kebijakan ini harapannya dapat mampu menggerakkan perekonomian di Kabupaten Karawang selain sektor Industri.

Secara demografis tenaga kerja yang terserap di sektor industri hanya sekitar 27\% dari penduduk usia kerja (BPS, 2017) salah satu faktornya dikarenakan masih rendahnya usia rata- rata sekolah yakni 7,4 tahun, sedangkan untuk bekerja di sektor industri memerlukan keahlian yang terspesialisasi. Walaupun terdapat Kawasan Industri di Kabupaten Karawang sebagai salah satu pengungkit roda perekonomian, akan tetapi pengangguran dan kemiskinan masih menjadi problematika di wilayah tersebut. Jika dibandingkan dengan wilayah lain yang memiliki Kawasan Industri sebagai roda perekonomiannya, kemiskinan kabupaten Karawang masih cukup tinggi atau sekitar $10,07 \%$ dari jumlah penduduk. Akan tetapi pertumbuhan kunjungan wisatawan ke Kabupaten Karawang masih rendah hal tersebut dapat dilihat pada Gambar 1.1.

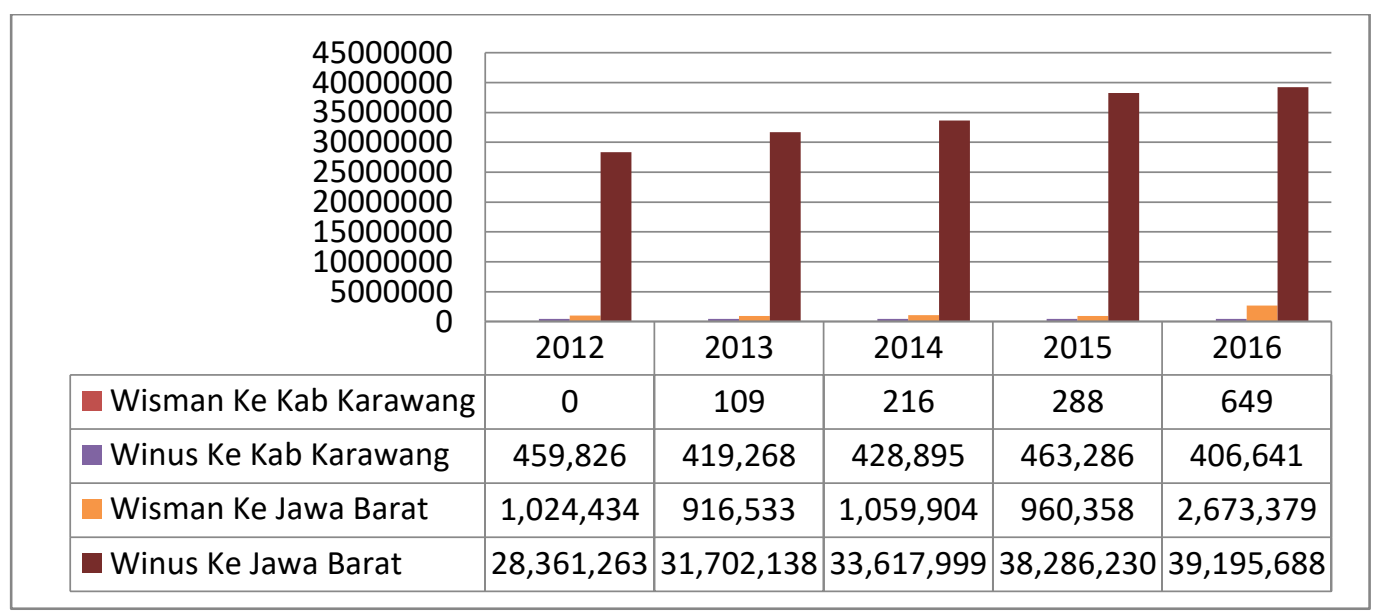

Gambar 1.1. Perbandingan Jumlah Kunjungan Wisatawan ke Jawa Barat dan Kabupaten Karawang

Sumber: Dinas Pariwisata dan Kebudayaan, 2017 diolah

Masih rendahnya keputusan wisatawan mengunjungi destinasi wisata di Kabupaten Karawang dapat diakibatkan karena persepsi Karawang sebagai kota industri, padahal di wilayah Karawang terdapat berbagai objek wisata. Maka dalam upaya meningkatkan jumlah pengunjung destinasi wisata diperlukan membangun merek yang kuat. Yunitasari dan Japarianto (2013) "merek merupakan persepsi yang dimiliki oleh pelanggan atau calon pelanggan bagaimana pengalaman pelanggan saat berhubungan dengan suatu perusahaan". Membangun merek tidak hanya untuk barang yang dihasilkan oleh industri manufaktur, tetapi juga jasa khuusunya jasa pariwisata yang menawarkan pengalaman. Peran pemasar penting, dimana saat ini pemerintah mengelola objek wisata juga berperan sebagai marketer (pemasar) 
seperti yang dilakukan oleh beberapa daerah di Indonesia. Dengan menerapkan alat penting untuk mengaitkan merek dan mempengaruhi pelanggan dalam membuat keputusan pembelian, menarik dan mempertahankan calon pelanggan dan pelanggan yang ada yaitu ekuitas merek (Nigam dan Kaushik, 2011). Upaya untuk membentuk daya saing kota adalah dengan City Branding, akan membuat daerah memiliki positioning dalam bidang pariwisata secara global (Sukmaraga dan Nirwana, 2016).

Kabupaten Karawang saat ini sedang mengembangkan potensi pariwisata mereka yaitu dengan membuat sebuah City Branding yaitu "Kota Pangkal Perjuangan" dengan tagline "Hayu Ka Karawang" karena Kabupaten Karawang merupakan salah satu kota sejarah perjuangan kemerdekaan Indonesia dan ditetapkan sebagai kawasan pariwisata Heritage. Kasali mengungkapkan bahwa City Branding sama sekali tidak untuk menggantikan strategi pembangunan daerah, ia hanya menjadi pelengkap. Meski begitu, City Branding ibarat brand promise yang harus ditepati (www.goodnewsfromindonesia.id, dunduh pada tanggal 5 januari 2018). Keputusan pengunjung mengunjungi suatu destinasi juga dapat dipengaruhi oleh citra destinasi tersebut, semakin positif citranya maka akan meningkatkan jumlah kunjungan (Maulani, 2014). Tujuan dari penelitian ini adalah menganalisis ekuitas merek objek wisata alam dan budaya di Kabupaten Karawang dari perspektif wisatawan, menganalisis City Branding Kabupaten Karawang, menganalisis bagaimana proses keputusan pengunjung dalam mengunjungi objek wisata alam dan budaya di Kabupaten Karawang, dan mengkaji secara empiris mengenai pengaruh ekuitas merek dan City Branding secara terhadap keputusan wisatawan mengunjungi objek wisata dan budaya di Kabupaten Karawang.

\section{LANDASAN TEORI DAN HIPOTESIS}

\subsection{Landasan Teori}

\subsubsection{Ekuitas Merek}

Merek melukiskan bagaimana pengalaman pelanggan saat berhubungan dengan suatu perusahaan. Maka dari itu, merek dapat dikatakan sebagai suatu persepsi yang dimiliki oleh pelanggan dan calon pelanggan (Yunitasari dan Japarianto, 2013). Kotler dan Keller (2016), menyatakan bahwa merek adalah nama, istilah, tanda, lambang, atau desain, atau kombinasi, yang dimaksudkan untuk mengidentifikasikan barang atau jasa dari salah satu penjual atau kelompok penjual dan mendiferensiasikan mereka dari para pesaing.

Ekuitas merek sebagai seperangkat aset dan kewajiban yang terkait dengan merek, termasuk nama dan simbolnya, yang dapat memberi dampak menguntungkan atau merugikan pada nilai-nilai yang timbul dari produk atau jasa (Aaker,1991; Yasin et al., 2007; Fouladivanda et al., 2013). Ekuitas merek merupakan suatu nilai tambah yang tercipta melalui nama di pasar dengan keuntungan atau pangsa pasar yang lebih baik (Yasin et al, 2007).

Perusahaan yang membangun mereknya dengan mengacu pada konsep merek berbasis pada pelanggan (Customer Based Brand Equity) dan mereka menerima ide tertentu mengenai sifat alami suatu strategi yang dimulai dari kebutuhan dan perilaku konsumen, maka strategi tersebut merupakan sesuatu yang kompetitif dan penuh tantangan dalam membangun sebuah merek (Prasetyo, 2016). 
Consumer-based brand equity adalah suatu aset yang memiliki empat dimensi yaitu brand awareness, brand associations, perceived quality dan brand loyalty (Leh \& Lee, 2011). Aaker (1996) menyatakan bahwa ekuitas merek dapat di evaluasi melaui brand loyalty, brand awareness, perceived quality, brand assosiation, dan other proprietary brand assets.

Brand Awereness merupakan kesanggupan konsumen mengenali atau mengingat suatu merek atau seberapa kuat suatu merek tertanam dalam benak/ingatan konsumen. Kesadaran merek merupakan kunci penting dalam ekuitas merek dan didefinisaikan sebagai kemampuan individu untuk mengingat dan mengenali sebuah merek. Perceived quality adalah persepsi konsumen terhadap kualitas atau keunggulan suatu produk atau jasa.

Apabila kualitas meningkat maka kesan konsumen pun meningkat, persepsi kualitas merupakan suatu penilaian pelanggan mengenai keunggulan produk dibandingkan dengan merek lain, keunggulan ini yang memotivasi pelanggan untuk membeli produk. Brand associations/asosiasi merek, sesuatu yang dikaitkan (dalam benak konsumen) dengan merek. Asosiasi ini kian menjadi kuat apabila dibangun atas dasar pengalaman konsumen baik secara individual maupun secara komunitas serta ditopang oleh kegiatan yang gencar dan efektif, asosiasi merek mengandung arti untuk konsumen dan merupakan sesuatu yang terkait dalam memori. Selain produk berwujud, kualitas tak berwujud, misalnya inovasi dan kekhasan juga diperhitungkan sebagai asosiasi merek. (Fouladivanda et al, 2013). Brand loyality yaitu kesetiaan pelanggan terhadap suatu merek tertentu, loyalitas merek sebagai keterikanan yang dimiliki pelanggan terhadap sebuah merek.

\subsubsection{City Branding}

Penerapan City Branding pada suatu daerah atau kota akan berpengaruh terhadap keputusan wisatawan untuk mengunjunginya (Prasetyo dan Maulani, 2016). Dalam hal ini ialah daerah Kabupaten Karawang. Kota atau Kabupaten yang sudah memiliki branding atau merek akan memiliki citra tersendiri bagi wisatawan karena memiliki ciri khas yang membedakan dengan kota-kota lain sehingga memberikan kenangan yang berbeda. City Branding pada awalnya difokuskan pada city brand image (Merrilees, et al., 2009). City Branding sebagai manajemen citra suatu destinasi melalui inovasi strategis serta koordinasi ekonomi, komersial, sosial, kultural, dan peraturan pemerintah (Moilanen dan Rainisto, 2009).

Dalam hal ini, merek diartikan sebagai Kabupaten Karawang. Selayaknya merek yang melekat dalam sebuah produk harus didukung oleh atribut yang mampu memenuhi persyaratan sebagi produk yang direkomendasikan untuk dikonsumsi (Prasetyo dan Maulani, 2016). Atribut yang dimaksud ialah pengembangan beberapa tempat yang ada dalam daerah tersebut, dalam hal ini bisa saja seperti tata kota, destinasi wisata, kebudayaan, dll. Tujuannya tidak lain ialah untuk banyak dikenal oleh para wisatawan. City Branding dapat dikatakan sebagai sebuah proses pembentukan merek melalui ikon, slogan, event, pameran, serta positioning yang baik, dalam berbagai media promosi (Purwianti dan Lukito, 2014). City Branding akan menggambarkan suatu pikiran, perasaan, asosiasi, dan ekspektasi yang datang dari beberapa orang pada saat mereka mendengar, melihat, dan merasakan konsep tersebut (Prasetyo dan Maulani, 2016). Itulah yang menjadikan salah satu dasar pemikiran bahwa wisatawan yang awalnya hanya mendengar berlanjut untuk memutuskan untuk mengunjungi. Memang tugas seorang pemasar ialah menyederhanakan keputusan konsumen bukan menambah informasi yang berujung pada lamanya proses keputusan dari konsumen. 
Menurut Merrilees, et al, (2009), City Branding adalah tentang tata cara berkomunikasi yang tepat untuk membangun merek kota, daerah, masyarakat yang tinggal di dalamnya berdasarkan pasar entitas mereka. City Branding adalah bagian dari merek tempat yang berlaku untuk kota tunggal atau wilayah keseluruhan dari sebuah negara. Syarat City Branding menurut Sugiarsono (2009) dalam membuat sebuah City Branding, terdapat beberapa kriteria yang harus dipenuhi, diantaranya:

1. Attributes: Do they express a city's brand character, affinity, style, and personality? (menggambarkan sebuah karakter, daya tarik, gaya dan personalitas kota)

2. Message: Do they tell a story in a clever, fun, and memorable way? (menggambarkan sebuah cerita secara pintar, menyenangkan dan mudah atau selalu diingat)

3. Differentiation: Are they unique and original? (unik dan berbeda dari kota-kota yang lain)

4. Ambassadorship: Do they inspire you to visit there, live there, or learn more? (Menginsipirasi orang untuk datang dan ingin tinggal di kota tersebut).

\subsubsection{Keputusan Berkunjung}

Dalam keterkaitannya dengan dunia kepariwisataan, keputusan pembelian diasumsikan sebagai keputusan berkunjung sehingga teori/konsep mengenai keputusan pembelian juga digunakan dalam keputusan berkunjung (Suwarduki et al, 2016). Keputusan mengunjungi objek wisata alam dan budaya di Kabupaten Karawang ini menggunakan konsep keputusan pembelian. Keputusan pembelian konsumen adalah membeli merek yang paling disukai dari berbagai alternatif yang ada, tetapi dua faktor bisa berada antara niat pembelian dan keputusan pembelian. Faktor pertama adalah sikap orang lain dan faktor yang kedua adalah faktor situasional. Oleh karena itu preferensi dan niat pembelian tidak selalu menghasilkan pembelian yang aktual (Kotler dan Armstrong, 2012). Proses pengambilan keputusan konsumen terkadang menjadi suatu proses yang kompleks dan konsumen dapat bergantung pada informasi-informasi mengenai merek dan produk secara spesifik serta pengalaman konsumen dapat mempengaruhi keputusan pembelian (Jiang \& Rosenbloom, 2005; Doostar, et al, 2012). Kotler \& Keller, 2016 mengemukakan bahwa dalam melakukan pembelian suatu produk dipengaruhi oleh berbagai faktor yaitu faktor budaya (budaya, sub budaya dan kelas sosial), faktor sosial (kelompok, referensi, keluarga, peran dan status) dan faktor pribadi (usia, pekerjaan, kendaraan, ekonomi, kepribadian, dan gaya hidup). Proses keputusan pembelian (Kotler \& Keller, 2016:) terdiri dari:

1. Pengenalan masalah (need recognition). Proses pembelian dimulai saat pembeli mengenali sebuah masalah atau kebutuhan. Pembeli merasakan perbedaan antara keadaan aktualnya dengan keadaan yang diinginkan.

2. Pencari informasi (information search). Konsumen yang tergugah akan melakukan pencarian informasi. Pada tingkat ini seseorang akan lebih peka terhadap informasi mengenai produk yang akan dicari, dengan pencarian aktif akan informasi yaitu mencari bahan bacaan, menelepon teman dan mengunjungi tempat dimana produk tersebut berada untuk mengetahui tentang produk yang dicari. Sumber informasi konsumen dapat berasal dari kelompok preferensi seperti keluarga atau teman, iklan, wiraniaga, penyalur, kemasan dan pajangan, media massa, serta bersumber dari dalam pemakaian produk.

3. Evaluasi alternatif - alternatif (evaluation of alternatives). Konsumen melakukan evaluasi yang berbeda - beda untuk membuat suatu pilihan antara obyek - obyek dengan atribut banyak. konsumen akan mempertimbangkan beberapa atribut tetapi memberikan bobot yang berbeda pada masing - masing atribut. 
4. Keputusan pembelian (purchase decision). Setelah konsumen membentuk preferensi atas merek - merek dalam kumpulan pilihan, kemudian konsumen membentuk niat untuk membeli produk yang paling disukai

5. Perilaku pasca pembelian (postpurchase behavior). Setelah pembelian suatu produk, konsumen akan mengalami tingkat kepuasan atau ketidakpuasan. Jika puas, maka kinerja produk melebihi harapan konsumen sehingga memungkinkan konsumen untuk mengkonsumsi kembali produk atau ketidakpuasan yang berujung pada perilaku tidak menggunakan/mengkonsumsi produk. Tugas pemasar tidak berakhir saat produk dibeli, melainkan berlanjut hingga periode pasca pembelian.

\subsection{Hipotesis Penelitian}

Hipotesis dalam penelitian ini adalah sebagai berikut:

H1: Ekuitas merek berpengaruh terhadap keputusan mengunjungi objek wisata dan budaya di Kabupaten Karawang

H2: City Branding berpengaruh terhadap keputusan mengunjungi objek wisata dan budaya di Kabupaten Karawang

H3: Ekuitas merek dan City Branding berpengaruh terhadap keputusan mengunjungi objek wisata dan budaya di Kabupaten Karawang

\section{III.METODE PENELITIAN}

Metode penelitian dalam penelitian ini adalah deskriptif dan verifikatif. Alat pengumpulan data yang berupa wawancara, observasi, studi kepustakan dan kuisioner dengan skala likert yang memiliki 5 (lima) alternatif jawaban. Dalam penelitian ini mengunakan data kunjungan pada tahun terakhir di tahun 2016 sebagai populasi yaitu sebesar 407.290. Pengambilan sampel dengan menggunakan rumus slovin sehingga didapatkan jumlah sampel sebesar 400 responden. Pengujian hipotesis yang dilakukan menggunakan analisis regresi berganda sedangkan dalam analisis deskriptif yang dilakukan dengan menentukan rentang interval yang mengacu pada rumus statistik sebagai berikut (Supranto, 2008):

$$
c=\frac{\mathrm{X}_{\mathrm{n}}-\mathrm{X}_{1}}{\mathrm{~K}}
$$

$\mathrm{c}=$ perkiraan besarnya (class width, class size, class length)

$\mathrm{k}=$ banyaknya kelas

$\mathrm{X}_{\mathrm{n}}=$ nilai observasi terbesar

$\mathrm{X}_{1}=$ nilai obervasi terkecil 
Jurnal Manajemen dan Bisnis: Performa Volume XV Nomor 2 September 2018

\section{IV.PEMBAHASAN}

\subsection{Gambaran Ekuitas Merek Destinasi Wisata Alam dan Budaya}

Untuk mengetahui gambaran ekuitas merek wisata alam dan budaya di Kabupaten Karawang dilakukan analisis deskriptif, analisa mengacu pada tabel range interval berikut:

Tabel 4.1. Kriteria Rentang Skor Ekuitas Merek

\begin{tabular}{llllll}
\hline Variabel & \multicolumn{1}{c}{ Skor } & $\begin{array}{c}\text { Rentang } \\
\text { Interval }\end{array}$ & Rentang Skor & $\begin{array}{c}\text { Rata- } \\
\text { Rata Skor }\end{array}$ & Kriteria \\
\hline Ekuitas & Miximum & & $7.200<12.960$ & $1<1,8$ & Sangat tidak baik \\
Merek & $5 \times 18 \times 400$ & $(36.000 \quad-$ & $12.960 \geq 18.720$ & $1,8 \geq 2,6$ & Tidak Baik \\
& $=36.000$ & $7.200) / 5=$ & $\mathbf{1 8 . 7 2 0}<\mathbf{2 4 . 4 8 0}$ & $\mathbf{2 , 6} \mathbf{3 , 4}$ & Cukup \\
& Minimum & 5.760 & $24.480 \geq 30.240$ & $3,4 \geq 4,2$ & Baik \\
& $1 \times 18 \times 400$ & & $30.240<36.000$ & $4,2<5$ & Sangat baik \\
& $=7.200$ & & & &
\end{tabular}

Sumber: pengolahan data, 2018

Berdasarkan hasil penilaian responden terhadap variabel ekuitas merek, diperoleh data sebagai berikut:

Tabel 4.2. Skor Ekuitas Merek

\begin{tabular}{lcc}
\hline Subvariabel & Rata- rata skor & Kriteria \\
\hline Brand Awareness & 3,13 & Cukup \\
\hline Brand Association & 3,43 & Baik \\
\hline Perceived Quality & 3,19 & Cukup \\
\hline Brand Loyalty & 3,53 & Baik \\
\hline Total Skor & 23.691 & Cukup \\
\cline { 1 - 2 } Rata- Rata Skor & 3,35 & \\
\hline
\end{tabular}

Sumber: pengolahan data, 2018

Berdasarkan hasil perhitungan di atas, gambaran mengenai ekuitas merek objek wisata alam dan budaya di Kabupaten Karawang berada pada nilai skor 23.691 yang berarti berkriteria cukup karena berada pada rentang interval $18.720<24.480$, dengan rata rata skor sebesar 3,35. Adapun rinciannya adalah sebagai berikut:

a. Brand Awareness objek wisata alam dan budaya di Kabupaten Karawang dinilai cukup dengan rata- rata skor sebesar 3,129. Sebesar 51,3\% wisatawan mengetahui objek wisata alam dan budaya di kabupaten Karawang dan sebesar 54\% wisatawan menyatakan mudah untuk mengingatnya. Akan tetapi mereka menilai bahwa objek wisata alam dan budaya masih belum terkenal sebesar $77 \%$ dan belum begitu sering mendengar mengenai objek wisata alam dan budaya yang ada di kabupaten Karawang.

b. Brand Association dari objek wisata alam dan budaya di Kabupaten Karawang dinilai cukup dengan rata- rata skor sebersar 3,4. Responden menilai bahwa dengan mendatangi objek wisata alam dan budaya yang ada memiliki kesan tersendiri. Responden mengasosiasikan bahwa objek wisata alam (wisata pantai) dan budaya (makam syakh kuro, situs candi jiwa, monumen rengasdengklok) merupakan objek wisata yang unik yang dapat bersaing dengan objek wisata di luar Kabupaten Karawang sebesar 49\%, misalnya seperti monumen rengasdengklok yang merupakan saksi bisu sejarah 
kemerdekaan Indonesia. Akan tetapi mayoritas wisatawan sebesar 83,5\% menilai masih kurang adalah mengenai akses menuju lokasi objek wisata yang dinilai belum mudah.

c. Perceived Quality. Persepsi kualitas wisatawan sebagai responden dinilai cukup dengan rata- rata skor sebesar 3,20. Mereka menilai bahwa wisata alam dan budaya yang ada merupakan objek wisata yang menyenangkan dan merekapun nyaman berada di lokasi tersebut. Tingkat ketersediaan fasilitas lainnya (seperti toilet dan parkir) dirasakan kurang oleh wisatawan sebesar 69,3\% dan sebesar 58\% wisatawan menyatakan bahwa ketersediaan petugas yang ada masih minim yang dapat membantu menjelaskan dengan baik mengenai objek wisata tersebut. Tingkat kebersihan di objek wisata yang masih kurang bersih seperti di objek wisata pantai dimana masih terdapat sampah yang belum terkelola dengan baik. Wisatawan sebagai responden pun menilai mengenai ketersediaan transportasi umum menuju lokasi yang belum tersedia maksimal.

d. Brand Loyalty. Loyalitas merek dinilai baik dengan rata-rata skor 3,532. Wisatawan sebagai responden dalam studi ini menyatakan bahwa mereka tertarik mengunjungi kembali objek wisata alam dan budaya di Kabupaten Karawang sebesar 51,8\% dan merekapun bersedia merekomendasikannya kepada pihak lain sebagai salah satu alternatif tujuan wisata.

\subsection{Gambaran City Branding}

Untuk mengetahui gambaran variabel City Branding dilakukan analisis deskriptif, analisa mengacu pada tabel range interval berikut:

Tabel 4.3. Kriteria Rentang Skor City Branding

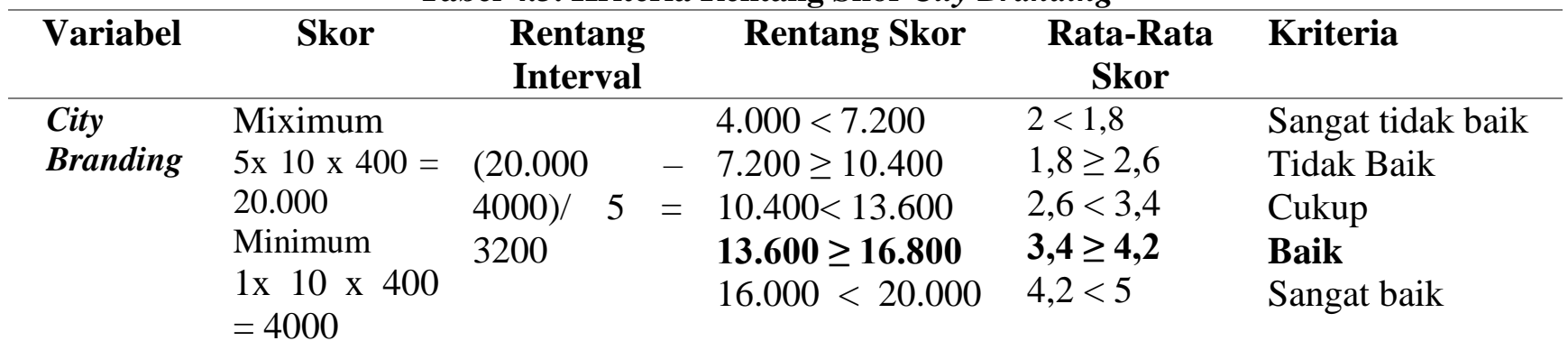

Sumber: pengolahan data, 2018

Berdasarkan hasil penilaian responden terhadap variabel ekuitas merek, diperoleh data sebagai berikut:

Tabel 4.4. Skor City Branding

\begin{tabular}{lcc}
\multicolumn{1}{c}{ Subvariabel } & Rata- rata skor & Kriteria \\
\hline Attributes & 3,43 & Baik \\
\hline Message & 3,53 & Baik \\
\hline Differentiation & 3,33 & Cukup \\
\hline Ambassadorship & 3,56 & Baik \\
\hline Total Skor & 13.881 & Baik \\
\hline Rata- Rata Skor & 3,47 & \\
\hline
\end{tabular}

Sumber: pengolahan data, 2018

Berdasarkan analisis deskriptif yang telah dilakukan, diperoleh hasil bahwa gambaran City Branding destinasi di Kabupaten Karawang terdapat pada kriteria baik dengan total skor 
13.881 karena berada pada rentang skor $13.600 \geq 16.800$ dan rata-rata skor sebesar 3,47 karena terdapat pada rentang nilai rata- rata 3,40 $\geq 4,2$. Adapun rinciannya sebagai berikut:

a. Attributes meliputi daya tarik dan fasilitas berada pada kategori baik dengan rata-rata skor sebesar 3,43. Daya Tarik, berdasarkan hasil penilaian wisatawan sebesar 55,3\% menyatakan bahwa Kabupaten Karawang memiliki daya tarik karena terdapat objek wisata alam dan budaya di Kabupaten Karawang yaitu pantai Tanjung Pakis, Pantai Tanjung Baru Pantai Pisangan, Makam Syakh Kuro, Situs Candijiwa dan Monumen Rengasdengklok dinilai oleh wisatawan memiliki daya tarik tersendiri. Sedangkan dari sisi fasilitas khusunya pada fasilitas penginapan di sekitar destinasi sebesar 58\% wisatawan menilai tersedia baik, akan tetapi dari sisi fasilitas transportasi umum sebesar 51,3\% wisatawan menilai bahwa tidak mudah dalam mendapatkan transportasi umum menuju destinasi. Juga dari sisi akses jalan, sebesar 56,1\% yang dinilai masih kurang baik menuju destinasi.

b. Message menggambarkan bahwa objek wisatawan memiliki kesan tersendiri berkategori baik dengan rata-rata skor 3,53 setelah berkunjung ke Kabupaten Karawang dengan mengunjungi beberapa objek wisata yang ditawarkan. Dari sisi kenyamanan, sebesar 55\% wisatawan menilai bahwa mereka merasa nyaman untuk berkunjung, hal tersebut didukung dari faktor masyarakat atau warga sekitar yang dinilai ramah dan sangat membantu. Wisatawan menilai bahwa mereka terkesan karena Kabupaten Karawang memiliki destinasi/objek wisata yang indah sebesar 54\%, sehingga wisatawan akan selalu mengingatnya.

c. Differentiation berada pada kategori baik dengan rata-rata skor sebesar 3,33. Differentiation merupakan keunikan Kab Karawang yang memiliki objek wisata yang bisa dibedakan dibandingkan dengan yang lain. Sebesar 55,3\% wisatawan menilai bahwa wisata alam dan budaya di kabupaten Karawang belum memiliki keunikan yang khas, dibandingkan dengan destinasi lainnya di luar Kabupaten Karawang, hal ini terjadi khususnya pada objek wisata pantai yang dinilai tidak berbeda dengan pantai lainnya.

d. Ambassadorship berada pada kategori baik dengan rata rata skor sebesar 3,56. Berdasarkan penilaian wisatawan sebesar 55\% menyatakan bahwa mereka merekomendasikan keluarga atau kerabat terdekat untuk berkunjung ke Kabupaten Karwang yang memiliki objek wisata alam dan budaya di Kabupaten Karawang.

\subsection{Gambaran Keputusan Mengunjungi}

Untuk mengetahui gambaran mengenai keputusan wisatawan dalam mengunjungi wisata alam dan budaya di Kabupaten Karawang, dilakukan analisis deskriptif yang mengacu pada tabel berikut:

Tabel 4.5. Kriteria Rentang Skor Keputusan Mengunjungi

\begin{tabular}{|c|c|c|c|c|c|}
\hline Variabel & Skor & $\begin{array}{l}\text { Rentang } \\
\text { Interval }\end{array}$ & Rentang Skor & $\begin{array}{c}\text { Rata-Rata } \\
\text { Skor }\end{array}$ & Kriteria \\
\hline $\begin{array}{l}\text { Keputusan } \\
\text { berkunjung }\end{array}$ & $\begin{array}{l}\text { Maximum } \\
5 \times 7 \text { x } 400= \\
\text { Minimum } \\
1 \times 7 \text { x } 400=\end{array}$ & $\begin{array}{l}(14.000- \\
2.800) / 5= \\
2.240\end{array}$ & $\begin{array}{l}2.800<5.040 \\
5.040 \geq 7.280 \\
7.280<9.520 \\
\mathbf{9 . 5 2 0} \geq \mathbf{1 1 . 7 6 0} \\
11.760<14.000\end{array}$ & $\begin{array}{l}3<1,8 \\
1,8 \geq 2,6 \\
2,6<3,4 \\
\mathbf{3 , 4} \geq \mathbf{4 , 2} \\
4,2<5\end{array}$ & $\begin{array}{l}\text { Sangat tidak baik } \\
\text { Tidak Baik } \\
\text { Cukup } \\
\text { Baik } \\
\text { Sangat baik }\end{array}$ \\
\hline
\end{tabular}

Sumber: Pengolahan data, 2018 
Berdasarkan hasil penilaian responden terhadap variabel keputusan berkunjung, diperoleh data sebagai berikut:

Tabel 4. 6. Skor Keputusan Mengunjungi

\begin{tabular}{lcc}
\hline \multicolumn{1}{c}{ Sub variabel } & Rata- rata skor & Kriteria \\
\hline Need for recognition & 3,61 & Baik \\
\hline Information search & 3,21 & Cukup \\
\hline Evaluation of alternatives & 3,78 & Baik \\
\hline Purchase decision & 3,44 & Baik \\
\hline Post purchase behavior & 3,59 & Baik \\
\hline Total Skor & 9763 & Baik \\
\hline Rata- Rata Skor & 3,49 & \\
\hline
\end{tabular}

Sumber: pengolahan data, 2018

Berdasakan hasil perhitungan, didapatkan nilai sebesar 10.2011 atau dengan rata- rata skor sebesar 3,49 yang berarti bahwa keputusan wisatawan mengunjungi wisata alam dan budaya di Kabupaten Karawang dinilai baik, karena berada pada rentang interval $9.520 \geq$ 11.760. Adapun rinciannya adalah sebagai berikut:

a. Need for recognition berada pada kategori baik dengan rata-rata skor sebesar 3,61. Need for recognition merupakan suatu proses dimana konsumen mengenali kebutuhannya. Dalam hal ini, wisatawan menilai bahwa dengan mengunjungi objek wisata tersebut sesuai dengan kebutuhannya yaitu berekreasi.

b. Information search berada pada kategori cukup dengan rata-rata skor sebesar 3,21. Konsumen akan tergugah mencari informasi sebelum melakukan keputusan pembelian dari berbagai sumber (Kotler dan Amstrong, 2012). Dalam hal ini, para wisatawan aktif melakukan pencarian informasi mengenai objek wisata alam dan budaya yang ada. Wisatawan menilai bahwa untuk mendapatkan informasi mengenai berbagai objek wisata yang ada di Kabupaten Karawang masih dinilai cukup. Akan tetapi dari sisi kejelasan informasi dirasakan mayoritas pengujung sebesar 60,8\% masih dirasa kurang.

c. Evaluation of alternatives berada pada kategori baik dengan rata-rata skor sebesar 3,78, dimana wisatawan membandingkan berbagai objek wisata yang ada sebelum mereka mengambil keputusan untuk berkunjung berdasarkan informasi yang didapatkannya.

d. Purchase decision berada pada kategori baik dengan rata-rata skor sebesar 3,59 dimana wisatawan merasa yakin dalam mengunjungi objek wisata yang sesuai dengan kebutuhannya.

e. Post Purchase behavior merupakan tindakan setelah mengkonsumsi suatu produk. Post Purchase behaviour berada pada kategori baik dengan rata-rata skor sebesar 3,59. Mayoritas wisatawan menyatakan bahwa mereka merasa puas sebesar 49,8\% dan sebesar $66,8 \%$ menyatakan ingin berkunjung kembali bersama kerabat ataupun keluarga. 
Jurnal Manajemen dan Bisnis: Performa Volume XV Nomor 2 September 2018

\subsection{Uji Hipotesis}

Untuk mengetahui pembuktian hipotesis $\mathrm{H} 1$ dan $\mathrm{H} 2$ secara parsial dapat dilihat pada Tabel coeficient berikut:

Tabel 4.7. Coeficient

\begin{tabular}{|c|c|c|c|c|c|c|}
\hline \multicolumn{7}{|c|}{ Coefficients $^{\mathrm{a}}$} \\
\hline \multirow{2}{*}{\multicolumn{2}{|c|}{ Model }} & \multicolumn{2}{|c|}{ Unstandardized Coefficients } & \multirow{2}{*}{$\begin{array}{c}\text { Standardized } \\
\text { Coefficients } \\
\text { Beta }\end{array}$} & \multirow[t]{2}{*}{$\mathrm{t}$} & \multirow[t]{2}{*}{ Sig. } \\
\hline & & B & Std. Error & & & \\
\hline \multirow[t]{3}{*}{1} & (Constant) & 3,748 & 1,366 & & 2,744 & ,006 \\
\hline & Brand_Equity & ,365 & 017 & ,730 & 21,099 &, 000 \\
\hline & City_Branding &,- 008 & ,026 &,- 011 &,- 320 & ,749 \\
\hline
\end{tabular}

Sumber: Pengolahan data, 2018

\subsubsection{Pengujian Hipotesis 1}

Berdasarkan Tabel 4.7, diperoleh bahwa koefisien jalur variabel ekuitas merek sebesar 0,730 dan nilai t hitung ekuitas merek adalah 21,099 lebih besar dibandingkan dengan nilai $\mathrm{t}$ tabel yaitu 1,96 ( $\mathrm{t}$ hitung $>\mathrm{t}$ tabel). Serta diperoleh nilai sig 0,00 dimana tingkat signifikasi sebesar 0,00 lebih kecil dari 0,05 (Sig 0,00 $\leq 0,05$ ) maka dari itu H1 diterima. Penelitian ini sesuai dengan Nigam dan Kaushik (2011), Leh dan Lee (2011), Irshad (2012), Gunawardane (2015), Akhtar et al (2016), yang menunjukkan bahwa terdapat pengaruh yang positif dan signifikan antara ekuitas merek terhadap keputusan mengunjungi destinasi wisata alam dan budaya di Kabupaten Karawang. Walaupun ekuitas merek objek wisata alam dan budaya di Kabupaten Karawang belum optimal maka dari itu dalam upaya meningkatkan jumlah wisatawan diperlukan membangun merek yang kuat, dengan komunikasi pemasaran yang terintegrasi dapat mempengaruhi calon pengunjung unuk mengunjungi objek wisata tersebut.

\subsubsection{Pengujian Hipotesis 2}

Berdasarkan Tabel 4.7,diperoleh hasil bahwa koefisien jalur variabel City Branding sebesar -0,011 dan nilai t hitung adalah - 0,320 lebih kecil dibandingkan dengan nilai t tabel yaitu 1,96 ( $\mathrm{t}$ hitung < t tabel), serta diperoleh nilai sig 0,749 dimana tingkat signifikasi yang lebih besar dari 0,05, maka dari itu $\mathrm{H} 2$ ditolak. Penelitian ini tidak sesuai dengan Malik et al (2016) dan Alpiannoor et al (2017) yang menyatakan bahwa City Branding berpengaruh terhadap keputusan berkunjung. Temuan dalam penelitian ini berbeda, tidak terdapat pengaruh City Branding terhadap keputusan wisatawan berkunjung, hal tersebut karena konsep City Branding belum diterapkan secara optimal, yang dimana strategi City Branding yang diimplementasikan hanya masih sekedar slogan dan logo saja. Sedangkan pada hakekatnya City Branding merupakan tata cara berkomunikasi yang tepat untuk membangun merek kota, daerah, masyarakat yang tinggal di dalamnya berdasarkan pasar entitas mereka (Merrilees et al, 2009). 


\subsubsection{Pengujian Hipotesis 3}

Dalam menguji kedua variabel independen secara bersamaan atau simultan berpengaruh terhadap variabel dependen, dapat dilihat pada tabel berikut:

Tabel 4.8. Anova

\begin{tabular}{|c|c|c|c|c|c|c|}
\hline \multicolumn{7}{|c|}{ ANOVA $^{a}$} \\
\hline \multicolumn{2}{|l|}{ Model } & Sum of Squares & df & Mean Square & $\mathrm{F}$ & Sig. \\
\hline \multirow[t]{3}{*}{1} & Regression & 3316,559 & 2 & 1658,280 & 224,783 &, $000^{\mathrm{b}}$ \\
\hline & Residual & 2928,769 & 397 & 7,377 & & \\
\hline & Total & 6245,328 & 399 & & & \\
\hline \multicolumn{7}{|c|}{ a. Dependent Variable: Decesion } \\
\hline \multicolumn{7}{|c|}{ b. Predictors: (Constant), Brand_Equity, City_Branding } \\
\hline
\end{tabular}

Dari tabel 4.8, terlihat bahwa nilai $\mathrm{F}$ hitung sebesar 224,783. Apabila dibandingkan dengan $\mathrm{F}$ tabel yaitu sebesar 3,36 maka $\mathrm{F}$ hitung $>\mathrm{F}$ Tabel dan juga nilai sig 0,00. Artinya bahwa ekuitas merek dan City Branding secara bersamaan (simultan) berpengaruh terhadap keputusan mengunjungi objek wisata alam dan budaya di Kabupaten Karawang, hal tersebut ditunjukan dengan nilai $\mathrm{F}$ hitung $>\mathrm{F}$ tabel dan dengan tingkat signifikasi 0,00 yang lebih kecil dari 0,05 .

\subsection{Koefisien Determinasi}

Tabel 4.9. Koefisien Determinasi

\begin{tabular}{|c|c|c|c|c|}
\hline \multicolumn{5}{|c|}{ Model Summary } \\
\hline Model & $R$ & $R$ Square & $\begin{array}{c}\text { Adjusted } R \\
\text { Square }\end{array}$ & $\begin{array}{l}\text { Std. Error of } \\
\text { the Estimate }\end{array}$ \\
\hline 1 &, $729^{\mathrm{a}}$ & ,531 & ,529 & 2,7161098 \\
\hline
\end{tabular}

Dari tabel 4.9, diperoleh bahwa ekuitas merek dan City Branding secara bersamaan memiliki hubungan yang kuat terhadap keputusan mengunjungi objek wisata alam dan budaya di Kabupaten Karawang dengan nilai koefisien $r$ sebesar 0,729. Dari tabel di atas juga diperoleh nilai koefisien determinasi ( $R$ square) sebesar 0,531 artinya bahwa ekuitas merek dan City Branding secara bersamaan berpengaruh terhadap keputusan mengunjungi objek wisata alam dan budaya di Kabupaten Karawang sebesar 53,1 \% dan sisanya 46,9\% dipengaruhi oleh faktor lain di luar model.

\section{KESIMPULAN DAN SARAN}

\subsection{Kesimpulan}

1. Ekuitas merek wisata alam dan budaya yang terdapat di Kabupaten Karawang saat ini dikategorikan cukup. Brand awareness merupakan dimensi yang paling rendah dengan kata lain, kesadaran wisatawan mengenai destinasi wisata alam dan budaya masih kurang, hal ini menjadi tantangan di masa yang akan datang.

2. City Branding dinilai baik dari keseluruhan aspek (attributes, message, differentiation, ambassadorship). Akan tetapi masih ada yang dinilai kurang yaitu dari sisi attributes dimana fasilitas yang masih kurang khususnya fasilitas transportasi umum dan akses infrastruktur jalan yang belum memadai. 
3. Variabel keputusan berkunjung ke destinasi wisata alam dan budaya di Kabupaten Karawang dikategorikan tepat, karena sesuai dengan kebutuhan wisatawan. Kebanyakan wisatawan memperhatikan core benefit product objek wisata alam dan budaya di Kabupaten Karawang sebagai tempat untuk berekreasi.

4. Terdapat pengaruh secara bersamaan (simultan) antara variabel City Branding dan ekuitas merek terhadap keputusan mengunjungi wisata alam dan budaya di Kabupaten Karawang sebesar 53,1\%, sedangkan sisanya dipengaruhi oleh faktor lain di luar model. Akan tetapi dalam uji parsial, tidak terdapat pengaruh antara variabel City Branding tarhadap keputusan mengunjungi wisata alam dan budaya di Kabupaten Karawang, sedangkan terdapat pengaruh antara variabel ekuitas merek tarhadap keputusan mengunjungi wisata alam dan budaya di Kabupaten Karawang,

\subsection{Saran}

1. Perlunya peningkatan pengeloaan pada objek wisata alam dan budaya di Kabupaten Karawang. Seperti ketersediaan fasilitas, kebersihan objek wisata serta akses jalan yang perlu dibenahi agar dapat memudahkan para wisatawan menuju tempat wisata, dan transportasi umum yang belum tersedia maksimal untuk mendukung akses menuju tempat wisata

2. Perlunya komunikasi pemasaran yang efektif di berbagai media seperti media cetak, elektronik, dan juga internet dalam upaya mempromosikan objek wisata alam dan budaya yang merupakan unggulan dari Kabupaten Karawang, sehingga masyarakat luar Kabupaten Karawang maupun masyarakat di luar Jawa Barat mengetahui objek wisata tersebut.

3. Penelitian selanjutnya diharapkan dapat dilakukan dengan menambahkan beberapa variabel yang tidak terdapat dalam model penelitian ini.

4. Penelitian selanjutnya diharapkan dapat membandingkan perilaku wisatawan berdasarkan usia dan asal domisili wisatawan sehingga dapat menjadi masukan untuk menetapkan strategi pariwisata selanjutnya.

\section{DAFTAR PUSTAKA}

Akhtar, N., Siddiqi, U. I., Ashraf, A., \& Latif, M. (2016). Impact of Brand Equity on Consumer Purchase Decision in L'Oreal Skincare Products. International Review of Management and Business Research, 5(3), 808.

Alpiannoor, M.A., Mawardi, K., Sanawiri. B. 2017.Pengaruh City Branding Serta Tagline "Kediri Lagi" Terhadap Minat Berkunjung Wisatawan Domestik Kabupaten Kediri

Data Dinas Pariwisata dan Kebudayaan Kabupaten Karawang

Dinas Pariwisata dan Kebudayaan Jawa Barat: Rencana Induk Pembangunan Kepariwisataan Jawa Barat tahun 2015 - 2025

Dokumen Dinas Pariwisata dan Kebudayaan Jawa Barat.2017. Pariwisara Jawa Barat Dalam Angka 2017

Doostar, M., Abadi, M. K. I., and Abadi, R. K. I. 2012. Impact of Brand Equity on Purchase Decision of Final Consumer Focusing on Products with Low Mental Conflict. Journal of Basic and Applied Scientific Research 2(10)10137-10144. ISSN 2090-4304. TextRoad Publication. 
Fouladivanda, F., Pashandi, M.A., Hooman, A., dan Khanmohammadi, Z. 2013. The effect of Brand Equity on Consumer Buying Behavior in term of FMCG in Iran. Interdiciplinary Journal of Contemporary Research in Business.. Institute of Interdisciplinary Business Research VOL 4, NO 9

Gunawardane, N., R. 2015. Impact of Brand Equity towards Purchasing Desition: A Situation on Mobile Telecommunication Services of Sri Lanka. Journal of Marketing Management June 2015, Vol. 3, No. 1, pp. 100-117 ISSN: 2333-6080 (Print), 2333-6099 (Online). Published by American Research Institute for Policy Development.

Irshad, W. (2012). Service Based Brand Equity, Measure of Purchase Intention, Mediating Role of Brand Performance. Academy of Contemporary Research Journal, Vol. 1(1), 110.

Kotler, P. dan Keller, K.L. 2016. Marketing Management 15e, Pearson Prentice Hall, USA, New Jersey.

Kotler, P. dan Armstrong, G. 2012. Principles of Marketing, Pearson Prentice Hall, USA, New Jersey

Leh, F. C. Y., dan Lee, G. C. 2011. Customer-Based Brand Equity: A Literature Review. Journal of Arts Science Commerce. International Refereed Research Journal. Vol.- II, Issue -1,January 2011. ISSN 2229-4686. www.researchersworld.com.

Leh, F. C.Y., dan Lee, G. C. 2011. Dimensions of Customer-Based Brand Equity: A Study On Malaysian Brands. Journal of Marketing Research and Case Studies. Vol. 2011 (2011), Article ID 821981, 10 pages. IBIMA Publishing. Malaysia.

Malik, M.1., Wilopo,. Mawardi, M.K. 2016. Pengaruh City Branding "The Soul Of Madura" dan Motivasi Wisatawan Terhadap Keputusan Berkunjung ke Kabupaten Sumenep

Maulani, T.S. (2014). Kinerja Bauran Pemasaran dalam Meningkatkan Citra serta Implikasinya terhadap Keputusan Mengunjungi Museum di Kota Bandung. Journal Banking and Management Review Vol. 03 No. 02. http://repository.ekuitas.ac.id/handle/123456789/261

Merrilees, B., D. Miller, and C. Herrington. 2009. Antecedents of residents' city brand attitudes. Journal of Business Research 62: 362-367.

Moilanen, T. dan Rainisto. (2009). How to Brand Nations, Cities and Destinations, A Planning Book for Place Branding. USA: Palgrave Macmillan.

Nigam, A., dan Kaushik, R. 2011. Impact of Brand Equity on Customer Purchase Decisions: An Empirical Investigation with Special Reference to Hatchback Car Owners in Central Haryana. IJCEM International Journal of Computational Engineering \& Management, Vol. 12, April 2011 ISSN (Online): 2230-7893 www.IJCEM.org

Povinsi Jawa Barat Dalam Angka, Badan Pusat Statistik Jawa Barat, 2017.

Prasetyo, M. H., dan Maulani, T. S., (2016). City Branding Effectiveness Strategy In The Context Of Tourist Satisfaction. Proceeding of the $2^{\text {nd }}$ International Conference on Economics \& Banking 2016 ( $2^{\text {nd }}$ ICEB) $24^{\text {th }}-25^{\text {th }}$ May 2016. Selangor. Malaysia.

Prasetyo, M. H. (2016). Aktivitas Integrated Marketing Communications Terhadap Brand Image Untuk Industri Rokok Kelas Mild. Jurnal Manajemen Teori dan Terapan (JMTT) Tahun 9, No. 1, April 2016. Surabaya.

Purwianti, L. \& Lukito, Y. R. (2014). Analisis Pengaruh City Branding Kota Batam Terhadap Brand Attitude (studi kasus pada stakeholder di Kota Batam). Jurnal Manajemen, Vol. 14 No. 1.

Sekaran, U. 2003. Research Methods For Business: A Skill Building Aproach, New YorkUSA: John Wiley and Sons, Inc

Sugiarsono. J, 2009, Bukan Asal Membuat Logo dan Slogan, Swa Sembada. http://202.59.162.82/swamajalah/sajian/details.php/cid=1\&id=9595.

Sugiono. 2008. Metode Penelitian Bisnis, Penerbit: Alfa Beta, Bandung 
Jurnal Manajemen dan Bisnis: Performa Volume XV Nomor 2 September 2018

Sukmaraga, A.A dan Nirwana, A. 2016. City Branding: Sebuah Tinjauan Metologis dengan Pendekatan Elaboratif, Praktis, dan Ilmiah. JADECS Vol 1, No1

Supranto, J. 2012 . Statistik Teori dan Aplikasi. Penerbit Erlangga

Suwarduki, P.R., Yulianto, E., dan Mawardi, M.K. 2016, Pengaruh Electronic Word Of Mouth Terhadap Citra Destinasi Serta Dampaknya Pada Minat Dan Keputusan Berkunjung (Survei pada Followers Aktif Akun Instagram Indtravel yang Telah Mengunjungi Destinasi Wisata di Indonesia). Jurnal Administrasi Bisnis (JAB)|Vol. 37 No. 2 Agustus 2016

www.goodnewsfromindonesia.id, dunduh pada tanggal 5 januari 2018

Yasin. M. N \& M. N. Noor dan O. Mohamad. 2007. Does image of country origin matter to brand equity. $\mathrm{J}$ of product and brand management

Yunitasari, C., dan Japarianto, E. 2013. Analisa Faktor-Faktor Pembentuk Personal Branding dari C.Y.N. Jurnal Manajemen Pemasaran Petra Vol. 1, No. 1, (2013) 1-8. Jurusan Manajemen Pemasaran Universitas Kristen Petra, Surabaya 